\title{
POMEN IN IZHODIŠČA VSEŽIVLJENJSKE KARIERNE ORIENTACIJE
}

Ministrstvo za delo, družino in socialne zadeve $R S$

Vspomin Vojki Žeromik

\section{POVZETEK}

Prispevek obravnava vseživljenjsko karierno orientacijo, ki se v širšem smislu ne nanaša le na izbiro poklica ali enkratno izbiro poklica, temveč na dinamično aktivnost nudenja pomoči posameznikom v njihovem poklicnem razvoju. Skozi svoje aktivnosti pomaga posamezniku pri usmeritvi za izbiro poklica skladno z njegovimi sposobnostmi, naravo poklica in družbenimi potrebami. Posameznika prav tako usmerja na področje dela, ki najbolj ustreza njegovim psihofizičnim lastnostim in kjer ima največ možnosti za uspeh.

Ključne besede: karierna orientacija, poklicna orientacija, psihosocialna obdobja, karierni razvoj, aktivnosti karierne orientacije, karierna orientacija v praksi

\section{THE SIGNIFICANCE AND MEANING OF A LIFELONG CAREER - ABSTRACT}

The article discusses lifelong career guidance, which does not comprise merely choosing a career or a profession as a single event: it understands it as a dynamic process providing individuals with assistance in their professional development. Through various activities, lifelong career guidance helps individuals to find a profession in accordance with their abilities, the nature of the profession and societal needs. Moreover, it gives individuals guidance on how to find the field of work which best suits their psychophysical characteristics and in which they are most likely to succeed..

Keywords: theatre as education, education and local development, creative learning, problem-solving oriented education, learning by doing, experiential learning.

UDK: 331.548

\section{ZGODOVINA POKLICNE ORIENTACIJE IN ODLOČITEV ZA POKLIC}

Prva potreba po poklicni orientaciji se je pojavila $\mathrm{z}$ nastankom industrijske družbe. $\mathrm{Ob}$ gospodarskih, tehnoloških in družbenih spremembah se na novo razvijejo raznovrstne vloge in naloge. Pojem orientacije postaja vedno bolj upravičljiv zaradi povečanih možnosti izbire, ki so na voljo vsakem posamezniku, in zahtev industrije, da dobi delovno silo, ki ustreza njenim potrebam, ter spričo nujnosti poskrbeti za primerno izobrazbo in poklicno pripravo mladih delavcev (Colman, 1996).
Poklicna oziroma karierna orientacija ima $\mathrm{v}$ Sloveniji že dolgo tradicijo, ki se je začela $\mathrm{z}$ vzpostavitvijo poklicnega svetovanja na takratnih območnih izpostavah zavoda za zaposlovanje v 50. letih. V 60. in 70. letih so bile uvedene svetovalne službe v osnovnih in srednjih šolah, vendar se področje še ni povsem formiralo kot stroka, zato je v različnih okoljih pojmovano na različne načine. V strokovni literaturi prihaja do mešanja tradicionalnih konceptov z nekaterimi novimi. Pojavljajo se izrazi ali termini, kot so: poklicno usmerjanje, poklicno svetovanje, karierno svetovanje, poklicna orientacija, vseživljenjska karierna orientacija ... 
Izraz poklicno usmerjenje se je začel opuščati v začetku 90. let prejšnjega stoletja. Niklanović (1998: 13) meni, da izraz poklicno usmerjanje ni ustrezen, ker implicira »nekoga, ki učenca usmerja «. Namesto tega se je začel uveljavljati izraz poklicno svetovanje, ki pa je po mnenju strokovnjakov (Rupar, 1999) preozek in zajema zgolj en vidik te dejavnosti. Konec 90. let se je pojavil nov izraz »poklicna orientacija«, ki implicira samostojno aktivnost posameznika, saj je $\mathrm{v}$ vseh pomenih orientacije »posameznik tisti, ki se orientira« (Niklanović, 1998: 13). »Izraz poklicna orientacija se nanaša na storitve in dejavnosti, namenjene pomagati posameznikom katerekoli starosti in na katerikoli točki v življenju, da sprejmejo odločitve o svojem izobraževanju, usposabljanju in zaposlitvi in da vodijo svojo kariero«(Bugnot, 2005). V Programskih smernicah - predlog 1999 je zapisano (Rupar, 1999: 13), da je poklicna orientacija »delo $\mathrm{z}$ učenci, učitelji, starši in vodstvom šole $\mathrm{z}$ namenom pomagati učencem pri izbiri in uresničevanju izobraževalne in poklicne poti«. Na področju izobraževanja odraslih pa se uporablja izraz informiranje in svetovanje (Niklanović, 2009). Cilje poklicne orientacije Jakelić (1990) opredeljuje s stališča:

- človeka kot posameznika, ki se usmerja v stroko in poklic, ki se najbolje prilega njegovim telesnim in psihičnim sposobnostim ter drugim osebnostnim lastnostim, torej kjer ima največ možnosti za uspeh;

- dela in poklica, da se usposablja v delovnem procesu in napreduje znotraj stroke in poklica;

- družbe (trga dela), v kateri naj bi pravilna razporeditev $\mathrm{v}$ poklicih pripeljala do družbenega napredka in blaginje. Tukaj je predvsem mišljeno, da bi bil vsak posameznik srečen in zadovoljen s poklicem, ki ga opravlja. Zato naj bi bili cilji poklicne orientacije humani in plemeniti.
Jakelić (1990) prav tako navaja naloge poklicne orientacije:

- spoznavanje osebnih lastnosti, kot so sposobnosti, potenciali, interesi, želje, zdravstveno stanje posameznika ...;

- spoznavanje želja in materialnega stanja družine posameznika, ki izbira šolo ali poklic;

- spoznavanje poklicev in šol ter pogojev, ki jih te postavljajo;

- spoznavanje trga dela;

- usklajevanje vseh zgoraj navedenih dejavnikov s ciljem svetovanja pri izbiri šole ali poklica;

- spremljanje posameznika in morebitna pomoč pri že izbranem šolanju ali opravljanju poklica;

- vključevanje vseh tistih, ki lahko sodelujejo in pomagajo pri procesu poklicne orientacije ter koordinaciji tega procesa.

Poklicna orientacija je kontinuiran proces, ki ga ne smemo razumeti kot enkratno pomoč, »nasvet « ali celo »ukaz«, ampak kot trajno aktivnost, ki je del procesa družbene produkcije, meni Lapajne (1978: 8) in dodaja tako kot Niklanović (1998: 10), da ga običajno delimo $\mathrm{v}$ tri faze, in sicer: poklicno prosvetljevanje (informiranje in vzgoja), poklicno svetovanje in poklicno spremljanje. Aktivnosti poklicne orientacije nekoliko razširi in opredeli tudi Podlogar (2001: 33), ki zajame: poklicno vzgojo in informiranje, diagnosticiranje, poklicno svetovanje, zastopanje, povratno informacijo, poklicno spremljanje svetovancev.

Termin poklicna orientacija je bil skladno $\mathrm{z}$ mednarodno sprejeto klasifikacijo prevzet iz francoskega jezika (»l'orientation professionnelle«, Jakelić, 1990: 31). Pri nas je uradno uveden pri opredelitvah temeljnih nalog svetovalne službe v Programskih smernicah predlog 1999 (Rupar, 1999). Izraz poklicna orientacija je danes najbolj razširjen, vendar se $\mathrm{v}$ gradivih in dokumentih EU od leta 2004 uporablja izraz karierna orientacija (Niklanovič, 2009). To je izraz, ki se nanaša na raz- 
lične dejavnosti (informiranje, svetovanje itn.), s katerimi želijo države članice EU pomagati mladim in odraslim pri spoznavanju njihovih lastnosti, pri spoznavanju možnosti za izobraževanje in zaposlovanje ter pri odločanju o kariernih ciljih in njihovem uresničevanju.

\section{VSEŽIVLJENJSKA KARIERNA ORIENTACIJA JE ODVISNA OD VSEŽIVLJENISKEGA UČENIA}

Karierna orientacija je opredeljena $\mathrm{v}$ dokumentu EU z naslovom Resolucija Sveta in predstavnikov držav članic, ki je nastal znotraj Sveta za povečevanje vpliva in moči politik, sistemov in praks $\mathrm{v}$ okviru vseživljenjskega svetovanja v Evropi. Resolucija sprejema definicijo, ki je bila predhodno dogovorjena med Evropsko komisijo in OECD (Lednik, 2006; Niklanović, 2007: 11): »Orientacija se $\mathrm{v}$ kontekstu vseživljenjskega učenja nanaša na vrsto aktivnosti, ki državljanom v vseh starostnih obdobjih in na katerikoli točki njihovega življenja omogočajo identifikacijo njihovih sposobnosti, kompetenc in interesov za sprejemanje odločitev na področju izobraževanja, usposabljanja in izbire poklica. Poleg tega jim omogoča vodenje njihovih življenjskih poti $\mathrm{v}$ učenju, delu in drugih okoljih, $\mathrm{v}$ katerih se teh kompetenc in sposobnosti naučijo in/ali jih uporabljajo. «V nadaljevanju resolucije so navedeni primeri služb in storitev, na katere se izraz nanaša (Niklanović, 2007: 12): »informiranje, dajanje nasvetov (advising), svetovanje (counselling), ocenjevanje kompetenc, mentorstvo, zastopanje in učenje veščin odločanja ter veščin vodenja kariere«. Resolucija je bila nadgrajena leta 2008 in karierno orientacijo postavlja v kontekst politike in zaposlovanja, poudarja pridobivanje veščin za vodenje lastne kariere in ravnotežje med osebnim in poklicnim življenjem ter določa štiri prioritete, in sicer (Svet EU, 2008):

1. spodbujati za vseživljenjsko pridobivanje veščin za vodenje kariere,
2. povečati dostopnost služb za karierno orientacijo,

3. razviti mehanizme za zagotavljanje kakovosti storitev karierne orientacije,

4. spodbuditi sodelovanje in koordinacijo med dejavniki na vseh ravneh.

Vseživljenjska karierna orientacija $\mathrm{v}$ Zakonu o urejanju trga dela (v nadaljevanju: ZUTD, 2010), ki je nadomestil stari Zakon o zaposlovanju in zavarovanju za primer brezposelnosti (ZZZPB), zajema aktivnosti, ki omogočajo identifikacijo sposobnosti, kompetenc in interesov za sprejemanje odločitev na področju zaposlovanja, izobraževanja, usposabljanja in izbire poklica ter omogoča vodenje življenjskih poti tako, da se posamezniki teh sposobnosti in kompetenc naučijo in jih uporabljajo. Aktivnosti vseživljenjske karierne orientacije so navedene $\mathrm{v}$ tretjem odstavku 18. člena ZUTD (2010):

- informiranje o trgu dela;

- samostojno vodenje kariere;

- osnovno karierno svetovanje;

- poglobljeno karierno svetovanje;

- učenje veščin vodenja kariere.

Kot storitve vseživljenjske karierne orientacije se lahko izvajajo tudi dejavnosti, ki so namenjene učencem, dijakom, študentom in njihovim staršem. Izvajajo se lahko $\mathrm{v}$ šolah, na univerzah ali strokovnih šolah, v ustanovah, namenjenih usposabljanju, na delovnem mestu, v prostovoljnem sektorju ali sektorju skupnosti in zasebnem sektorju. Dejavnosti lahko potekajo individualno ali skupinsko ter so lahko osebne storitve ali storitve na daljavo (kar vključuje telefonsko pomoč in spletne storitve). Vključujejo ponudbo informacij o poklicih (v tiskani obliki, obliki na podlagi IKT in drugih oblikah), orodja za ocenjevanje in samoocenjevanje, svetovalne intervjuje, programe izobraževanja za poklicno rast (ki pomagajo posamezniku razvijati zavedanje samega sebe, zavedanje priložnosti in znanja vodenja kariere), programe preizkušanja poklicev (da preizkusijo možnosti, preden se 
zanje odločijo), programe iskanja dela in storitve pri prehodu v drugo zaposlitev (Bugnot, 2005). Menim, da je zelo pomembno, da se mladi med šolanjem učijo tudi o delu in ne le za delo. Karierna orientacija je v vmesnem poročilu o uresničevanju lizbonske strategije iz leta 2004 navedena kot ena od štirih prioritetnih aktivnosti, ki ustvarjajo odprta, privlačna

Pomembno je, da se mladi med šolanjem učijo tudi o delu. in dostopna učna okolja. Zato države članice EU krepijo vlogo, kakovost in koordiniranost služb za karierno orientacijo, da bodo slednje lahko dajale večjo podporo državljanom pri vseživljenjskem učenju.

Pri nas se izraz karierna orientacija nanaša na naslednje dejavnosti (Lednik, 2006; Niklanović, 2007: 11):

- na vseh stopnjah rednega izobraževanja: informiranje, svetovanje, poklicna vzgoja, programi razvoja kariere itn.,

- v zaposlovanju (ZRSZ): informiranje v centrih za informiranje in poklicno svetovanje, poklicno svetovanje na uradih za delo, delno tudi zaposlitveno svetovanje in nekateri programi (delavnice), ki se izvajajo v okviru programa APZ - aktivne politike zaposlovanja (predvsem programi motiviranja, načrtovanja in vodenja kariere, delavnice za iskanje zaposlitve, klubi za iskanje zaposlitve itn.),

- informiranje in svetovanje v izobraževanju odraslih (centri ISIO ipd.),

- razvoj karier zaposlenih (aktivnosti, ki jih izvajajo v delovnih organizacijah).

Glede na trenutno veljavni termin, v duhu časa in skladno $\mathrm{z}$ dokumenti EU v nadaljevanju prispevka uporabljam izraz »karierna orientacija «, vendar se ne odpovedujem izra$\mathrm{zu} »$ poklicna orientacija «, ki je za zdaj najbolj razširjen v strokovni literaturi. Iz zgoraj navedenega je razvidno, da je izraz karierna orientacija opredeljen bistveno širše kot izraz poklicna orientacija. Prav tako vključuje več različnih dejavnosti. Menim, da izraza nista sinonimna ali da prvi nadgrajuje drugega, kot je razvidno iz nekatere sodobne strokovne literature. Poklicno orientacijo namreč vidim kot del karierne orientacije, kot proces ali aktivnost oziroma načrtovanje strokovnega dela, v okviru katere posameznik izbira najbolj ustrezen način šolanja za pridobitev ali spremembo poklica. Ko pride do želenega poklica, v okviru tega gradi svojo kariero s pomočjo aktivnosti vseživljenjske karierne orientacije, kot jih navaja ZUTD (2010).

$\mathrm{V}$ prispevku se predvsem osredotočam na mlade in proces oziroma načrtovanje aktivnosti pri prvi izbiri poklica.

\section{OPREDELITEV VSEŽIVLJENJSKE KARIERNE ORIENTACIJE}

Pri predstavitvi karierne orientacije izhajam iz psiholoških teorij, ki v ospredje postavljajo človeka, njegovo motivacijo, znanje, osebnostne lastnosti, sposobnosti in zahteve poklica. Poleg psiholoških teorij izbire poklica obstajajo tudi nepsihološke teorije izbire poklica (teorija slučaja, ekonomske teorije, sociološke teorije), ki determinirajoče dejavnike fenomena izbire poklica iščejo zunaj posameznika. Tako individualnih razlik, kot so inteligentnost, interesi in druge pomembne osebnostne lastnosti, ne povezujejo z izbiro poklica.

Izbira poklica je po mnenju skupine avtorjev (Ginzberg, Ginsburg, Axelrad in Herma, v: Lapajne, 1997; Brančić, 1986) razvojni proces, v katerem ne gre le za odločitev o izbiri poklica, temveč tudi za zaporedje odločitev, ki jih človek sprejema v daljšem obdobju. Vsaka odločitev je precej določena s predhodnimi odločitvami in odvisna od razvojne faze posameznika. $\mathrm{V}$ razvoju se posameznik uči o sebi (svojih potrebah, interesih, sposobnostih, dosežkih ...), hkrati pa se uči o realnem okolju (možnostih in potrebah gospodarskega, družbenega in kulturnega okolja). To učenje naj bi omogočilo zadovoljitev potreb posameznika, ki nenehno išče ravnotežje med obema vrstama dejavnikov. Posameznik 
mora napraviti kompromis med tistim, kar želi, in danimi možnostmi. Procesa izbire poklica pa ni mogoče ponoviti, zato je $\mathrm{v}$ dobršni meri nepovraten, meni skupina avtorjev (prav tam), na kar Ginzberg (prav tam) dodaja, da verjame, da se proces izbire poklica sploh ne konča in da se lahko ujema s posameznikovim celotnim delovnim življenjem.

Pripravo na izbiro poklica moramo prilagoditi zrelosti posameznika, poudarja tako Super (v: Lapajne, 1997; Brančić, 1986) kot tudi Žerovnik (1997). Podobno kot intelektualni, čustveni in telesni razvoj predpostavlja intelektualno, čustveno in telesno zrelost, tako po Superju (Lapajne, 1997) poklicni razvoj predpostavlja razlike med posamezniki v poklicni zrelosti. Pri tem avtor misli najmanj na dvoje (prav tam: 33):

- na položaj posameznika na razvojni lestvici vedenja, ki sega od »raziskovanja« do »upada«, ter

- na dejansko vedenje posameznika glede na njegovo kronološko starost.

Parsons (Lapajne, 1997: 15; Lapajne, 1978) opisuje poklicno svetovanje kot stopenjski proces, $\mathrm{v}$ katerem se po eni strani spoznavajo lastnosti posameznika, po drugi pa analizirajo podatki o poklicih, ki so na voljo: »Posameznik pride do zrele, racionalne odločitve na podlagi sistematične primerjave svojih lastnosti (psihofizičnih sposobnosti, znanja, omejitev ...) z zahtevami poklica.«Super (Brančić, 1986) v svoji teoriji napeljuje na dejstvo, da ima vsak posameznik karakterističen model sposobnosti, interesov in drugih osebnostnih lastnosti, prav tako vsak poklic zahteva karakterističen skup teh lastnosti. Večja konsistentnost osebnostnih lastnosti posameznika z lastnostmi, ki jih zahteva neki poklic, pomeni, da obstaja verjetnost večje uspešnosti in zadovoljstva posameznika pri delu. Individualne potenciale posameznika usmerja zadovoljstvo, ki izhaja iz nagrajene uporabe sposobnosti, ustrezne zadovoljitve potreb, družbeno sprejetega izražanja interesov in družbene realizacije vrednot. To lahko privede, ni pa nujno, meni Super (Lapajne, 1997), do sinteze, katere rezultat je zrela integrirana oseba. Njeni potenciali so harmonično usklajeni v njej sami, hkrati pa so tudi prilagojeni potencialom in potrebam družbenega okolja. Torej, »Orientacija pomeni pripraviti posameznika, da se začne zavedati samega sebe in da napreduje pri študiju in $\mathrm{v}$ poklicu glede na spremenjene življenjske raz-

Karierna orientacija ne poteka ločeno od socialnih kriterijev in izvora mladostnikov. Prav tako imajo svojo vlogo dejavniki, povezani s spolom, kot tudi socialni in etnični izvor mladostnikov. Po besedah Hollanda (v: Lapajne, 1997; Niklanović, 2005) je izbira poklica izraz celotne osebnosti. Skladno s svojo teorijo sklepa, da je za uspešno in ustrezno izbiro poklica značilna skladnost med osebnostjo posameznika in lastnostmi okolja. Medtem ko tip osebnosti vpliva na odločitve in izbire poklicnih okolij, so posameznikove odločitve odvisne tudi od hierarhije ravni (level hierarchy), ki jo opredeljujeta posameznikova inteligentnost in vrednotenje samega sebe (self-evaluations). Funkcija vrednotenja samega sebe je funkcija posameznikove življenjske zgodovine, kar zadeva socialno-ekonomski položaj, gospodarske razmere, izobrazbeno raven in zdravje. Starši, socialni položaj, kultura in drugi zunanji vplivi oblikujejo posameznika na različne načine. Na podlagi teh izkušenj se posameznik raje ukvarja z enimi dejavnostmi kot z drugimi. Pozneje se priljubljene dejavnosti razvijejo v močne interese. Razvijejo se tudi tiste sposobnosti, ki so s tem interesom povezane. Interesi in sposobnosti pa oblikujejo pri posamezniku izhodišče za način zaznavanja, razmišljanja in delovanja. Ko posameznik odraste, se razvoj ne ustavi, temveč se nadaljuje skladno z okolji, v katera se vključuje (Niklanović, 2005). Zadovoljstvo, stabilnost in uspeh pri poklicnem delu so po njegovem odvisni predvsem od tega, ali je posameznik izbral okolje, ki ustreza njegovem tipu osebnosti, v manjši meri pa je rezultat splošne inteligentnosti, znanja in podobnih dejavnikov, ki so jih poudarjale starejše teorije. Od njih je odvisna predvsem raven, ki jo posameznik doseže v poklicnem okolju (v: Lapajne, 1997; Niklanović, 2005). 
mere, in sicer z dvojnim namenom, da prispeva k napredku družbe in človeka« (La Malfa in Borsini, v: Colman, 1996: 23).

Da so pri izbiri poklica pomembni tudi motivacijski dejavniki, ki v glavnem niso zavestni, meni Roe (v: Lapajne, 1997; Brančić, 1986). Stopnja motivacije za dosego poklicnega cilja je odvisna od zastopanosti in intenzivnosti strukture posameznikovih potreb. Razlike v motivaciji pojasnjujejo različne dosežke oseb z enakimi sposobnostmi. Ključne determinante izbire poklica $\mathrm{v}$ adolescenci in odraslosti vidi Roe (prav tam) v družinski atmosferi in temeljnih držah staršev do otroka $v$ ranem otroštvu. Družinska atmosfera vpliva na vrsto poklicnih dejavnosti, medtem ko genetična struktura in nezavedni vzorec porabe fizične energije vplivata na raven, ki jo delavec doseže.

\section{ERIKSONOVA TEORIJA PSIHOSOCIALNEGA RAZVOIA V LUČI STOPENJ RAZVOJA KARIERNE ORIENTACIJE}

Avtorji, kot sta Super in Ginzberg, opredeljujejo več razvojnih obdobij v poklicnem razvoju. Starostne zamejitve pojmujeta kot približne, ne kot toge, raziskovanje poklicev $\mathrm{v}$ mladostništvu pa kot ključno sestavino posameznikovega pojma o »poklicnem sebi«, menita Marjanovič Umkova in Zupančičeva (2004). To se lahko navezuje tudi na Eriksonovo teorijo psihosocialnega razvoja, kjer gre za soočanje s psihološkimi in socialnimi problemi, ki jih mora posameznik uspešno rešiti, če želi napredovati na naslednjo stopnjo. Te zahteve, ki jih Erikson (Marjanovič Umek, Zupančič, 2004) navaja $\mathrm{v}$ kronološkem zaporedju razvoja posameznika, so: dosledna skrb in nega, uravnavanje samostojnosti, uravnavanje nesprejemljivih želja, učenje družbeno smiselnih spretnosti, znanj, navad, opredelitev identitet, intimnost in reprodukcija, skrb za naslednje generacije ter soočanje s smrtjo.

Super (Marjanovič Umek, Zupančič, 2004) poklicno odločanje razlaga $\mathrm{v}$ okviru pojma o »poklicnem sebi.«Po tej razlagi naj bi imel posameznikov pojem o sebi osrednjo vlogo pri izbiri poklica, do številnih sprememb $\mathrm{v}$ pojmu poklicnega sebe pa naj bi prišlo $\mathrm{v}$ mladostništvu in zgodnji odraslosti. Ginzberg (Marjanovič Umek, Zupančič, 2004) razlaga razvoj poklicnega odločanja skozi tri obdobja: domišljijsko obdobje in obdobje preizkušanja, ki mu sledi realistično obdobje. Domišljijsko obdobje se po Ginzbergu (prav tam) starostno prekriva z otroštvom (od 6. do 11. leta), ki ga Super (Lapajne, 1997: 32; Brančić, 1986) pojmuje kot stopnjo rasti in zameji od rojstva do 14. leta. Super (prav tam) to obdobje razdeli na fantazijsko (od 4. do 10. leta), v katerem so dominantne potrebe, pomembno je igranje vlog v fantaziji. Po besedah Ginzberga (prav tam) $\mathrm{v}$ tem obdobju otroci pridobivajo podatke o različnih poklicih in o njih fantazirajo. Mislijo in verjamejo, da lahko postanejo vse, kar si želijo. Glavna determinanta želja in dejavnosti je tisto, kar je otroku všeč, kar Super (prav tam) opredeljuje kot interese. V tem obdobju (11 do 12 let) otrok oblikuje trajnejše interese in vzpostavlja lasten odnos do okolja. Interesne dejavnosti, v katere se vključuje, doživlja bolj zavestno, bolje ocenjuje svoje sposobnosti, odkriti zna, kaj ga pri posamezni dejavnosti privlači in kaj odbija, pravi Žerovnikova (1997). Sposobnosti ali zmožnosti (med 13. in 14. letom), kakor jih razlaga Super (Lapajne, 1997: 32; Brančić, 1986), dobivajo večjo težo, upoštevajo se zahteve dela vključno $\mathrm{z}$ usposabljanjem in treningom. Njegove poklicne želje usmerjajo poznavanje poklica, blišč, imenitnost in imajo malo skupnega $\mathrm{z}$ odločitvijo, ki jo bo izbral v svoji prihodnosti. Poleg tega $\mathrm{v}$ različnih časih običajno daje prednost različnim poklicem. Erikson (Marjanovič Umek, Zupančič, 2004) ta čas razdeli v dve razvojni obdobji. Prvo je zgodnje otroštvo (med 3. in 6. letom), v katerem se otrok sreča z družbenimi prepovedmi in jih $\mathrm{v}$ situaciji konfliktnosti, psihosocialni krizi iniciativnosti nasproti kriv- 
di postopno ponotranji in začne razvijati super ego. Pri reševanju te krize mu lahko pomagajo starši z načrtnim preusmerjanjem njegove energije na smiselne in sprejemljive dejavnosti. Drugo obdobje Erikson (Marjanovič Umek, Zupančič, 2004) pojmuje kot srednje in pozno otroštvo (med 6. in 11. letom) oziroma kot začetek pubertete, ko se način delovanja otrokovega ega kakovostno preoblikuje v smislu pridobivanja konkretnih in smiselnih spretnosti ter znanj, ki jih ceni družba, v kateri otrok živi. Izraža se $\mathrm{v}$ njegovi pozornosti in marljivem ustvarjanju, spoštovanju pravil, sodelovanju, spoštovanju skupinskega napora pri obvladovanju konkretnih nalog. Če v primerjavi s socialnimi standardi po lastni oceni ali oceni drugih otrok ne deluje primerno, se doživlja kot manjvreden od drugih. Tako se oblikuje psihosocialna kriza marljivost nasproti občutka manjvrednosti.

$\mathrm{V}$ zgodnjem in srednjem mladostništvu se posamezniki navadno znajdejo v obdobju preizkušanja (od 12. do 17. leta), na prehodu iz domišljijskega $\mathrm{v}$ realistično obdobje poklicnega odločanja, menita Ginzberg in Super (Marjanovič Umek, Zupančič, 2004; Brančić, 1986; Lapajne, 1997). V tem času se posameznik zave resnosti izbire bodočega poklica in upošteva svoje potrebe, interese, zmožnosti, vrednote in priložnosti. To razvojno obdobje Erikson (Marjanovič Umek, Zupančič, 2004) pojmuje kot mladostništvo (med 12. in 15. letom), v katerem so za mladostnika moteče tudi nove socialne zahteve, zaradi katerih prihaja $\mathrm{v}$ konflikt z drugimi in s samim seboj. Mladostniku se v tem obdobju kažejo številne možnosti, glede katerih se mora opredeliti in si ustvariti svoje mesto v družbi. Dogajanje, zaradi katerega so mladostniki negotovi glede tega, kaj in kdo so, kdo in kako naj postanejo, oblikuje psihosocialno krizo identiteta nasproti identitetna zmedenost. Ginzberg (prav tam) pravi, da otroci (navadno med 11. in 12. letom) najprej ocenijo poklicne možnosti z vidika presoje svojih interesov, kasneje se zavedo tudi izobraževalnih zahtev in pomena osebnostnih značilnosti za opravljanje različnih poklicev. Med 13. in 14. letom starosti začnejo upoštevati svoje sposobnosti, in sicer pri soočanju z izobraževalnimi zahtevami. Nazadnje v srednjem mladostništvu pri izbiri poklica vse bolj upoštevajo vrednote, pri čemer nekaterim vrstam poklicev pripisujejo višjo vrednost kot drugim (skladno s svojimi zaznanimi interesi in sposobnostmi). Ginzberg (prav tam) meni, da v prehodu v pozno mladostništvo pride do spremembe od subjektivne $\mathrm{k}$ bolj objektivni, torej bolj realistični izbiri, zato to obdobje imenuje realistično.

Naslednjo razvojno fazo, ki se začne z 18. letom, Ginzberg (Lapajne, v: Niklanović, 1997; Brančić, 1986) pojmuje kot realistično obdobje, ki obsega tri razvojne stopnje: eksploracijo, kristalizacijo in specifikacijo. Super (Lapajne, 1997) to obdobje, ki ga časovno omeji od 15. do 24. leta, pojmuje kot stopnjo raziskovanja. V tem obdobju Super (prav tam) oblikuje dimenzije poklicne zrelosti, kot so kristalizacija, specifikacija, implementacija, stabilizacija in konsolidacija. V fazi eksploracije po Ginzbergu in kristalizacije po Superju (Niklanović, 1997; Brančić, 1986) posameznik oblikuje predstave o poklicu, ki se prepletajo z njegovim globalnim pojmom o sebi. Prav tako mladi posameznik integrira osebnostne preference s sposobnostmi in zmožnostmi ter jih povezuje $\mathrm{z}$ družbenimi in osebnimi vrednotami, pri čemer skuša začasne izbire preizkušati v praksi. Med 18. in 22. letom se mladostniki nahajajo v obdobju prehoda, ki ga Super (prav tam) imenuje obdobje specifikacije. V tem času zožijo svojo poklicno izbiro in se vključijo $\mathrm{v}$ dejavnost, ki jim bo omogočila opravljanje nekega poklica. Ta razvojna faza se ujema z Ginzbergovo fazo kristalizacije, za katero je značilen jasen poklicni vzorec, utemeljen na uspehih in neuspehih, ki jih je posameznik izkusil v predhodni fazi (prav tam). Presoja realnosti dobiva večjo težo, ko mladostnik vstopa na trg dela ali $\mathrm{v}$ poklicno usposabljanje, da bi implementiral samopodobo. Približno med 22. in 24. letom, 
čas, ki ga Super (prav tam) imenuje obdobje implementacije, naj bi mladostniki končali svoje izobraževanje za poklic in se prvič zaposlili. Po opredelitvi navidez primernega področja najde $\mathrm{v}$ njem začetno zaposlitev in jo preizkuša kot delo za vse življenje. Erikson (Marjanovič Umek, Zupančič, 2004) to obdobje pojmuje kot zgodnjo odraslost, za časovno mejo pa postavi starosti med 22 do 24 in 40 do 45 let. Psihosocialna kriza, ki se razvije v tem obdobju, nastane po eni strani zaradi močne težnje po intimnosti, pripravljenosti deliti in vzajemno usmerjati vse pomembne vidike življenja $\mathrm{z}$ drugo osebo in po drugi strani zaradi antagonizmov, ki se pojavljajo med različnima partnerjema. Pri ljudeh, ki psihosocialno krizo intimnost nasproti izolaciji razrešijo v smeri negativnega pola, pride do izolacije, izločenosti iz medsebojnega odnosa, pri tistih, ki jo razrešijo pozitivno, pa se razvije nova moč ega oziroma ljubezen. O specifični ustrezni karieri pa se odločajo šele v obdobju stabilizacije po Superju (prav tam), in sicer približno med 25. in 35. letom ali v fazi specifikacije po Ginzbergu (prav tam), v kateri posameznik izbere pozicijo ali se poklicno specializira. V drugi polovici zgodnje odraslosti, ki jo Super (prav tam) imenuje konsolidacija, posamezni teži $\mathrm{k}$ napredovanju v specifični delovni karieri in doseganju višjega poklicnega položaja.

Stopnjo vzdrževanja (45 do 64 let), o kateri govori Super (Niklanović, 1997; Brančić, 1986), Erikson (Marjanovič Umek, Zupančič, 2004) pojmuje kot stopnjo odraslosti, v kateri konflikt med skrbnostjo zase, samonagrajevanjem ter skrbnostjo za druge oblikuje psihosocialno krizo generativnosti (ustvarjalnosti) nasproti stagnaciji. V tem obdobju pragmatične sposobnosti posameznik praviloma doseže najvišjo raven razvoja, podobno kot specifične sposobnosti, vezane na poklic, ki ga odrasli opravlja, v poklicni karieri prihaja do vrha, pri posebnih skupinah odraslih pa ustvarjalnost doseže najvišjo raven razvoja, čeprav je obdobje vrha odvisno tudi od vrste dejavnosti, v kateri ljudje izražajo svoje ustvarjalne sposobnosti, menita Schaie in Wills (Marjanovič Umek, Zupančič, 2004).

Stopnjo upada (65 let in več, kakor jo določa Super (Niklanović, 1997; Brančić, 1986)), Erikson (Marjanovič Umek, Zupančič, 2004) pojmuje kot pozno odraslost (zrela doba), ki traja do smrti. Včasih v letih uradne upokojitve (upočasnitev), včasih pa v pozni stopnji vzdrževanja, se ritem dela upočasni, obveznosti se prenesejo na druge ali pa se narava dela prilagodi upadajočim zmožnostim. Številni nadomestijo zaposlitev za polni delovni čas $\mathrm{z}$ občasnimi in krajšimi zaposlitvami. $\mathrm{V}$ tem obdobju se ljudje ukvarjajo s pregledovanjem, spraševanjem o svojem življenju, kar oblikuje psihosocialno krizo integracija nasproti življenjskemu obupu (Erikson, v: Marjanovič Umek, Zupančič, 2004). Ljudje, ki sprejmejo svoje življenje kot nekaj, kar se je moralo zgoditi, razvijejo novo moč ega, modrost, ki se izrazi tako, da najdejo vrednost in smisel v življenju kljub njegovi končnosti na individualni ravni, nasprotno temu pa drugi začnejo zavračati svoje življenje in druge ljudi, so negativistični, zamerljivi, sovražni, nezadovoljni in nazadujejo na stopnjo otroške odvisnosti. To obdobje se kronološko precej pokriva z obdobjem po upokojitvi, ki je za ljudi pomemben življenjski dogodek in zahteva prilagajanje na nove okoliščine. Turner in Helms ( Marjanovič Umek, Zupančič, 2004) menita, da je za večino ljudi upokojitev pričakovan dogodek, ki ga ugodno sprejmejo, za manjšino (zlasti za tiste, ki se močno poistovetijo s poklicno vlogo in/ ali so imeli v poklicu visok družbeni položaj), pa je upokojitev izrazito stresen dogodek.

Tako kot velja za vsako časovno mejo, so tudi tu velike razlike med posamezniki. Vendar vsi nekoč doživijo popolno prenehanje zaposlitve, nekateri zlahka in na prijeten način, drugi s težavami in razočaranji, nekateri pa šele s smrtjo. 


\section{DEIAVNIKI V PROCESU KARIERNE ORIENTACIJE}

V nadaljevanju želim umestiti karierno orientacijo v prakso, zato izhajam iz definicij karierne orientacije in iz psiholoških teorij izbire poklica. Te so pomembne tako za mladostnike kot tudi za odrasle, ker se dotikajo posameznikovih zmožnosti, izobraževalnega vedenja, socialnega vedenja in drugih posebnosti. Pri tem sledim Colmanu (Colman, 1996: 89), ki pravi: »... da je treba mladega človeka voditi, da začenja postopoma razumevati lastno individualno, družinsko in družbeno stvarnost ter okolje, v katerem živi.«

Žerovnikova (Poklicno ..., b. d.) navaja nekatere ponavljajoče se izkušnje, ki jih je imela pri delu z mladimi v procesu poklicnega odločanja, ko ti na to življenjsko odločitev niso bili dovolj dobro pripravljeni. Za različne starostne skupine so značilne različne težave, s katerimi se posamezniki srečujejo ob sprejemanju poklicne odločitve.

Učenci osnovnih šol:

- se ne zavedajo pomena odločitve,

- se premalo poznajo,

- nimajo dovolj razvitih interesov,

- preslabo poznajo izobraževalne poti in možnosti,

- preslabo poznajo poklice,

- niso sposobni samostojno sprejeti poklicne odločitve,

- imajo posebne potrebe idr.

Dijaki srednjih šol:

- imajo premalo ali »preveč« interesov,

- ne vedo, kaj želijo, nimajo opredeljenih poklicnih interesov,

- se premalo poznajo,

- ne poznajo dejavnosti in poklicev,

- ne poznajo izobraževalnih poti in študijskih programov,

- starši, prijatelji idr. jim priporočajo študijske programe, ki jih ne veselijo,

- zanimivi se jim zdijo poklici, ki so v javnosti odmevni, vendar jih ne poznajo in ne vedo, ali so zanje primerni,
- imajo premalo točk za vpis v želeni program,

- ne znajo določiti treh programov za prijavo,

- odločajo se med nadaljnjim izobraževanjem in takojšnjo zaposlitvijo,

- se ne želijo odločiti idr.

Študenti:

- ne vedo, kaj jih zares veseli,

- ne poznajo sami sebe, svojih lastnosti,

- ne poznajo dejavnosti, poklicev s svojega področja,

- ne poznajo razmer na trgu dela ali se bojijo, da ne bodo našli zaposlitve,

- ne vedo, kakšno obliko zaposlitve naj izberejo,

- odločajo se med takojšnjo zaposlitvijo in nadaljnjim študijem,

- imajo poklicne cilje, pa ne vedo, kako pristopiti k njihovemu uresničevanju,

- doživljajo »študijsko« krizo, ne vedo, ali naj vztrajajo v študijskem programu ali ne,

- zamenjali bi študijski program, pa ne vedo, katerega naj izberejo, idr.

Mladi z manj priložnostmi:

- obremenjuje jih slaba samopodoba,

- se obtožujejo za neuspeh,

- se ne poznajo,

- ne vedo, kaj jih veseli,

- ne poznajo možnosti za pridobitev izobrazbe,

- ne poznajo dejavnosti, poklicev,

- ne poznajo izobraževalnih programov,

- ne poznajo možnosti za pridobitev kvalifikacije,

- ne vedo, kakšen izobraževalni program ali poklic naj bi izbrali,

- ne vedo, kako naj se ponovno vključijo v izobraževanje,

- ne poznajo poti za ureditev svojega statusa,

- ne vedo, kakšne možnosti so jim zagotovljene, idr.

Brezposelni:

- imajo neustrezno izobrazbo,

- obremenjuje jih negativna izkušnja,

- se obtožujejo za neuspeh,

- se ne poznajo, ne vedo, kaj jih zares veseli, 
- postajajo malodušni,

- postajajo nemotivirani za ponovno zaposlitev,

- nimajo opredeljenega poklicnega cilja,

- ne poznajo razmer na trgu dela,

- ne poznajo zaposlitvenih možnosti,

- ne poznajo dejavnosti, poklicev,

- imajo idejo, pa ne vedo, kako jo uresničiti,

- premalo poznajo poti za urejanje samozaposlovanja,

- so pred dilemo, ali nadaljnje izobraževanje, dokvalifikacija, prekvalifikacija ali vztrajanje pri doseženi izobrazbi in poklicu,

- posledice odločitve bo čutila tudi družina, idr.

Zaposleni:

- niso zadovoljni s svojim poklicem,

- niso zadovoljni s svojo zaposlitvijo,

- niso zadovoljni s svojo izobrazbo,

- radi bi kaj drugega, pa ne vedo, kaj bi izbrali,

- ne poznajo svojih potencialov,

- ne poznajo možnosti, poklicev, dejavnosti,

- ne morejo se odločiti, ali nadaljnje izobraževanje ali ne,

- odločitev povzroči večje življenjske spremembe,

- nimajo dovolj poguma za spremembe idr.

Da bi na takšen življenjski korak, kot je poklicno odločanje, mlade dobro pripravili, teorija poklicne orientacije postavlja $\mathrm{v}$ ospredje:

1. elemente poklicnega odločanja,

2. pravočasno pripravo na poklicno odločitev. Ta teoretična izhodišča veljajo za vse skupine mladih in odraslih, spreminjajo pa se metodološki pristopi pri posameznih populacijah.

\section{ELEMENTI POKLICNEGA ODLOČANJA}

Izbira poklica je osebna odločitev, pa vendar je tesno povezana z družbenimi potrebami in možnostmi. Nanjo vplivajo motivacija, poznavanje različnih dejavnosti/ poklicev, informacije o možnostih izobraževanja in zaposlovanja. Po besedah Žerovnikove (1997) morajo mladi pred poklicno odločitvijo prav zaradi različnih možnosti predvsem spoznavati sami sebe, svoje sposobnosti in lastnosti ter tudi svoje prednosti. Ugotoviti morajo, kaj jih zanima in kaj ne. »Posebno dobro se morajo na poklicno odločitev pripraviti mladostniki, saj nimajo izkušenj, znanja in zrelosti, ki bi jim pomagale. V tem obdobju se odločajo za izobraževalne poti, ki jih lahko vodijo k cilju ali pa jih od njega oddaljujejo « (Žerovnik, 1997: 15).

Špendetova (2002) pravi, da se glede na hitrost spreminjanja zunanjih oziroma družbenih dejavnikov poklicna orientacija odziva tako, da posameznika pripravlja na sprejemanje poklicnih odločitev ob upoštevanju njegovih značilnostih s tem, da:

- razvija sposobnosti in interese posameznika;

- omogoča raziskovanje novih dejavnosti in poklicev;

- omogoča sprejemanje delovnih nalog, ki jih narekujejo nagle spremembe na področju trženja novih izdelkov, storitev in delovnih mest.

Med elemente poklicnega odločanja sodi načrtovanje aktivnosti karierne orientacije in korakov do sprejetja poklicne odločitve.

\section{Načrtovanje aktivnosti karierne orientacije}

Colman (1996: 56) načrtovanje poklicne poti prikazuje skozi tri ravni delovanja:

1. spoznavanje samega sebe - to je sposobnost, da posameznik ugotovi, kakšne so njegove osebnostne značilnosti, kot so interesi, nagnjenja in želje, značaj, kar vse pogojuje kakršnokoli šolsko ali poklicno izbiro;

2. pridobivanje informacij o specifičnih in objektivnih podobah zunanje stvarnosti (potek izobraževanja, zaposlovanja in delo, poklicne panoge in podobno), ki vplivajo na posameznikove odločitve;

3. izbiranje med različnimi možnostmi $\mathrm{z}$ uvajanjem ustrezne strategije odločanja; $\mathrm{s}$ tem je mogoče odbrati in aktivno uporabljati pridobljene informacije za dosego 
smotrov, ki si jih je posameznik postavil. Žerovnikova (1997) pri obravnavi poklicnega odločanja mladih prav tako izhaja iz psiholoških teorij izbire poklica, pri čemer se naslanja na Superja, Colmana in Hollanda. Pri tem meni, da je treba mladega človeka, ki se pripravlja na poklicno odločitev, seznaniti $\mathrm{S}$ pomenom osebnostnega razlikovanja in $\mathrm{z}$ objektivnimi možnostmi. Preden bo sprejel poklicno odločitev, bo moral:

1. pregledati osebnostne vrednote in stališča, pri katerih obstaja tudi tesna povezava s poklicnim odločanjem in delom. Poznavanje teh je pomemben element prepoznavanja osebnih značilnosti in iskanja ciljev, ki se ujemajo s posameznikovim prepričanjem. Med mnogimi elementi, ki mladim ponujajo izhodiščno točko za njihovo poklicno izbiro, so vrednote, kakor so želja po znanju, ustvarjalnost, uveljavljanje samega sebe, tveganje, prizadevnost ali lastna zadostitev;

2. prepoznati osebnostne lastnosti in značilnosti, kot so:

- trajnejši interesi in zanimanje za študij ali poklic, ki nam niso dani ob rojstvu in se v obdobju odraščanja spreminjajo. Na njihov razvoj vpliva več različnih dejavnikov, kot so razvoj otrokove osebnosti, okolje in vzgoja, deloma spol, socialno-kulturne razmere $\mathrm{v}$ družini ter otrokove sposobnosti ali nesposobnosti. »Z razvojem otrokove osebnosti se množijo tudi interesi, ki postopoma postanejo trajnejši in manj labilni« (Žerovnik, 1997: 19). Odločilni interes posameznika za nadaljnje izobraževanje ali delo je zelo odvisen od njegove uspešnosti v šoli, sposobnosti za učenje, odnosa okolja do šolanja in izobrazbe ter od njegovih vrednot in interesov. Zato je treba otroke že zgodaj seznaniti z različnimi dejavnostmi in jih spodbujati, da bodo $\mathrm{v}$ njih tudi aktivno sodelovali;

- sposobnosti, ki posamezniku omogočajo uspešno opravljanje aktivnosti ter boljše rezultate, uspehe in učinke pri učenju in delu. Med sposobnostmi se najpogosteje omenja inteligentnost, vendar so za opravljanje poklica pomembne tudi številne druge, kot so umske, zaznavne, čutne, psihomotorične in fizične sposobnosti. Mladostniki lahko tudi sami prepoznajo svoje potenciale, ki jih lahko razvijajo pri šolskem in domačem delu $\mathrm{v}$ različnih aktivnostih in $\mathrm{v}$ stikih z vrstniki. Slabši šolski uspeh lahko povzroči, da se mladostnik kljub dobrim sposobnostim odvrača od zahtevnejšega izobraževalnega programa in se odloči za manj zahtevnega, za takojšno zaposlitev ali izstop iz nadaljnjega izobraževanja, kakor se dogaja z osipniki ali z mladimi z manj priložnostmi;

- osebnostna struktura, s katero označujemo predvsem temperament in značaj osebe. Oboje vpliva na vsakodnevno in trajnejše ravnanje posameznika $\mathrm{v}$ različnih življenjskih situacijah, med katere sodita tudi šola in delo;

3. poiskati primerne informacije in jih uporabiti, kar pomeni, da mora:

- iskati najpomembnejše informativno gradivo in se posvetovati z osebami, ki mu lahko pomagajo pri izbiri nadaljnjega izobraževanja;

- iskati informativno gradivo in izkušene osebe, ki mu lahko pomagajo, da bo laže razumel ekonomsko stanje in položaj poklica, v katerega bi se rad vključil;

- na podlagi pridobljenega gradiva in navodil naj kritično presodi vse možne odločitve, pri tem pa mora upoštevati svoje cilje in osebnostne značilnosti;

4. preveriti vse $» z a \ll$ in $» p r o t i \ll ~ o b ~ p o s a m e-$ zni izbiri;

5. za uresničitev odločitve si bo moral pripraviti »akcijski načrt«, ki obsega različne aktivnosti za preverjanje in razvijanje potencialov ter pridobivanje informacij o poklicih, izobraževanju ter trgu dela. 


\section{Koraki do sprejetja poklicne odločitve}

Da bo posameznik izpolnil vse pogoje, mora biti na odločitev pripravljen. Ta priprava se začne zgodaj, v obdobju najintenzivnejšega razvoja interesov. Sistematična priprava na poklicno odločitev je proces, ki se po trditvi Donalda E. Superja (Lapajne, 1996) pri običajni populaciji začne $\mathrm{z}$ intenzivnim razvojem interesov v obdobju 11. in 12. leta, v celoti pa obsega štiri korake, pravi Žerovnikova (1997: 26), ki zahtevajo dolgotrajno pripravo:

1. Prvi korak je sistematično razvijanje interesov pri otrocih in mladostnikih. Primerne so različne aktivnosti, s katerimi se otroci in mladostniki ukvarjajo $\mathrm{v}$ šoli in zunaj nje. Podlaga za oblikovanje njihovih poklicnih interesov bo peščica tistih, s katerimi se bodo radi ukvarjali.

2. Drugi korak obsega spoznavanje dejavnosti in področij $\mathbf{v}$ najširšem smislu, $s$ katerimi se mladi delno seznanijo že pri razvijanju interesov, vendar jim je treba omogočiti spoznavanje dejavnosti $\mathrm{v}$ njihovem »delovnem« okolju. S takšnimi aktivnostmi pridobivajo najbolj splošne informacije.

3. Tretji korak pomeni spoznavanje poklicev, sem sodijo aktivnosti, kot so pridobivanje in poglabljanje najrazličnejših informacij ter pridobivanje izkušenj.

4. Četrti korak obsega iskanje poklicnih ciljev, to je zadnje dejanje pred izbiro poklica oziroma zaposlitvijo.

V obdobju intenzivnega dozorevanja človeka posamezne aktivnosti v zgoraj opisanih korakih vodijo $\mathrm{k}$ temu, da pozameznik širi svoje poklicne možnosti in $\mathrm{v}$ procesu prepoznavanja samega sebe izbor zoži ter končno izbere tiste, ki mu bodo $\mathrm{v}$ delovnem obdobju nudile največ zadovoljstva in uspeha.

\section{PRIPRAVA NA POKLICNO ODLOČITEV}

Človek si mora za pripravo na poklicno odločitev vzeti dovolj časa. Začne se že v osnovni šoli s prvimi spoznanji o bistvu dela in konča s prenehanjem delovne aktivnosti.

Čim pomembnejša je odločitev, tem daljše so priprave, pravi Žerovnikova (1997). To še posebej velja za mladostnike pred prvo poklicno odločitvijo, saj so brez izkušenj, ki bi jim lahko pomagale pri poklicnem opredeljevanju. Sprejemanje poklicne odločitve je proces, ki se po trditvi Superja (Lapajne, 1996) pri običajni populaciji začne $\mathrm{z}$ intenzivnim razvojem interesov v 11. in 12. letu. Mladi z manj priložnostmi in mladi s težavami v socialni integraciji pa potrebujejo še aktivnosti socialnega vključevanja, razvijanje odnosa do lastnega, tujega in skupinskega dela (Grcić in Žerovnik, 2005). Proces sprejemanja poklicne odločitve skupaj z njegovimi dejavniki je skupen vsem in se ponovi večkrat $\mathrm{v}$ življenju, pred vsako novo poklicno odločitvijo.

Slika 1: Aktivnosti socialnega vključevanja

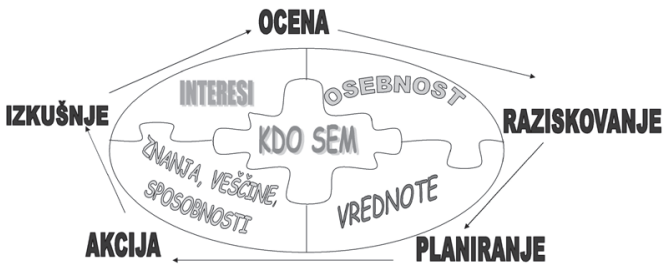

Vir: LiveCareer (b. d.). Priredil in oblikoval Grcić (2008).

V Tabeli 1 izhajam iz Superjevega poklicnega razvoja in podajam shematski prikaz sistematičnih priprav na izbiro poklica po starostnih obdobjih, ki ustrezajo 1. in 2. stopnji Superjevega poklicnega razvoja. Dodajam še mlade z manj priložnostmi in mlade $\mathrm{s}$ težavami $\mathrm{v}$ socialni integraciji ter potrebne aktivnosti in način njihove izvedbe za zgoraj omenjeno populaci- 
Tabela 1: Shematski prikaz sistematičnih priprav na izbiro poklica po starostnih obdobjih

\begin{tabular}{|c|c|c|}
\hline Subjekti & Vrste aktivnosti & Načini izvedbe aktivnosti \\
\hline $\begin{array}{l}\text { Mladi z mani priložnostmi } \\
\text { (težavami v socialni } \\
\text { integraciii) }\end{array}$ & $\begin{array}{l}\text { Učenje socialnih veščin } \\
\text { Grajenje pozitivne samopodobe }\end{array}$ & $\begin{array}{l}\text { Ustvarialne delavnice, } \\
\text { mladinske delavnice, } \\
\text { poklicna vzgoja v osnovni šoli, } \\
\text { delo s starši }\end{array}$ \\
\hline $\begin{array}{l}\text { Učenci } \\
\text { od 11. do 13. leta }\end{array}$ & Razvijanje interesov & $\begin{array}{l}\text { Obisk kulturnih prireditev, živalskega vrta, } \\
\text { botaničnega vrta, muzejev, galerij; } \\
\text { obisk kmetii, obrtnih delavnic, ateliejev, različnih podjetii; } \\
\text { interesne dejavnosti: ustvarialne delavnice, tabori, } \\
\text { kolonije, tečaji, krožki }\end{array}$ \\
\hline $\begin{array}{l}\text { Učenci med } \\
\text { 13. in 15. letom }\end{array}$ & $\begin{array}{l}\text { Razvijanje interesov, splošne in konkretne } \\
\text { informacije o poklicu in šolanju, o delu, } \\
\text { redkeje o delovnem mestu; informacije o } \\
\text { dijaških domovih, štipendijah }\end{array}$ & $\begin{array}{l}\text { Interesne dejavnosti: ustvarjalne delavnice, tabori, } \\
\text { kolonije, tečaji, krožki; } \\
\text { obisk ustanov, kulturnih prireditev; } \\
\text { obisk podjetii, obrtnih delavnic; } \\
\text { obisk srednjih šol, dijaških domov; } \\
\text { obisk specializiranih knjižnic }\end{array}$ \\
\hline $\begin{array}{l}\text { Dijaki med } \\
\text { 15. in 19. letom }\end{array}$ & $\begin{array}{l}\text { Razvijanje interesov, konkretne informacije o } \\
\text { poklicu, izobraževanju, študentskih domovih, } \\
\text { štipendiranju, zaposlovanju; pridobivanje } \\
\text { neposrednih delovnih izkušenj }\end{array}$ & $\begin{array}{l}\text { Interesne dejavnosti: ustvarjalne delavnice, tabori, } \\
\text { kolonije, tečaji, krožki; } \\
\text { obisk višjih in visokih šol, NUK-a, univerzitetnih knjižnic; } \\
\text { obisk kadrovskih služb in poslovodnih delavnic v } \\
\text { različnih podjetjih; } \\
\text { obisk občinskih upravnih organov; } \\
\text { obisk študentskega servisa; } \\
\text { počitniško delo, delovna praksa }\end{array}$ \\
\hline Študenti, brezposelni & $\begin{array}{l}\text { Iskanje poklicnih ciljev, konkretne informacije } \\
\text { o poklicu, zaposlitvenih možnostih, } \\
\text { pridobivanje neposrednih delovnih izkušenj }\end{array}$ & $\begin{array}{l}\text { Povezovanje z delovnimi organizacijami; } \\
\text { dodatno poklicno usposabljanje; } \\
\text { občasno delo, delovna praksa, vključevanje v projekte }\end{array}$ \\
\hline
\end{tabular}

Vir: Žerovnik (1997: 27). Priredil in oblikoval Grcić (2008).

jo. Ko se pri tej ciljni skupini dosežejo prvi pozitivni rezultati učenja socialnih veščin, se lahko uspešneje nadaljuje priprava na poklicno odločitev po korakih, ki so predvideni za ta proces. Celoten proces se zato podaljša, ker je treba $\mathrm{v}$ ta postopek vključiti otroke čim prej, takoj po ugotovitvi razmer. $\mathrm{V}$ vsakem primeru je uspeh večji, če se posameznik začne pripravljati na poklicno odločitev že pred prehodom $\mathrm{v}$ puberteto.

Aktivnosti temeljijo po eni strani na domnevi diferencialne psihologije, da se ljudje med seboj razlikujejo v številnih lastnostih, po drugi strani pa na rezultatih analize o razlikah med poklici $\mathrm{v}$ tem, koliko in kako so posamezne lastnosti pomembne za uspešno delo $\mathrm{v}$ tem ali onem poklicu. Pomembnost teh aktivnosti vidim v doseganju skladnosti posameznikovih najpomembnejših interesov $\mathrm{z}$ izbiro šole, izobraževanja, poklica ali dela. Tako je posameznik lahko bolj zavzet, bolj pozoren, se laže uči in si bolje zapomni stvari, laže rešuje težave, ob uspehu pa je resnično zadovoljen in srečen.

\section{NOVA SPOZNANIA O KARIERNI ORIENTACIJI}

Dobro načrtovane in organizirane aktivnosti karierne orientacije postajajo $\mathrm{v}$ sodobni družbi vse pomembnejše. Države članice OECD in Evropske unije izvajajo vseživljenjske strategije učenja kot tudi politike, ki izboljšujejo zaposljivost njihovih državljanov. Za uspešno izvajanje takšnih strategij in politik morajo imeti državljani veščine za samostojno upravljanje svoje izobrazbe in zaposlitve. To pa 
zahteva, da imajo vsi državljani dostop do visokokakovostnih informacij in svetovanja o izobraževanju, usposabljanju in delu.

Karierna orientacija je kontinuirano izvajanje aktivnosti, ki posameznikom omogočajo razvoj kompetenc in sposobnosti, da bi lahko sprejemali samostojne odločitve o izobraževanju in poklicni poti. Njena naloga je po besedah Colmana (1996) doseči spoznavni, etični in družbeni proces ter proces presojanja, ki se nenehno razvija, dokler ne privede človeka do tega, da dozori in lahko samostojno načrtuje svojo prihodnost $\mathrm{v}$ povezavi z okoljem, $\mathrm{v}$ katerem živi. Usmerjena je na ljudi in na skupino poklicev, ki najbolj ustrezajo njihovim lastnostim, sposobnostim in znanju, kar v nadaljevanju pomeni delovno uspešnost. Menim, da bi morala biti zagotovljena v celoti, skozi vse socialne odnose in življenjska obdobja, tj. v družini, vrtcu, šoli, kasneje tudi na zavodu za zaposlovanje. Odraslemu morajo biti v strokovnih institucijah in pri delodajalcih ponujene tudi morebitne prekvalifikacije in dokvalifikacije.

Karierna orientacija pomeni pridobiti izkušnje, razviti in prepoznati interese, poglobiti se $\mathrm{v}$ svoja prepričanja in vrednote, soočiti se $\mathrm{z}$ delovnimi navadami in osebnimi značilnostmi svetovancev ter usposobiti vsakega izmed njih do te meje, da si ustvari zadovoljivo življenje ob stalnem spreminjanju delovnega okolja. Dobro poznavanje samega sebe, poznavanje poti zbiranja informacij in pomoči ter obvladovanje veščin odločanja so zelo pomembno znanje, ki ga potrebuje otrok, mladostnik in odrasel človek. To znanje je postalo $v$ današnjem svetu ključno za vsakega posameznika, saj mora biti v svojem poklicnem življenju fleksibilen, sposoben prilagajanja in spreminjanja svoje poklicne poti. Poklic ne pomeni le vrste dela, ki ga nekdo opravlja, temveč tudi družbeni položaj, družbeno vlogo in stil življenja v celoti.

Menim, da izbira zaposlitve in uspešno opravljanje poklica izhaja iz posameznikove motivacije, znanja, osebnostnih lastnosti in sposobnosti.
Tematika karierne orientacije je bogata in razvejena. Spričo takšne celovitosti sta potrebni usklajevanje in tesno sodelovanje vseh ustanov, ki imajo pristojnosti na tem področju. Nobena izmed teh ustanov pa sama zase ne more uspešno zadovoljiti mnogovrstnega povpraševanja uporabnikov.

V Evropi je danes veliko svetovalcev, ki končajo posebno smer študija in pridobijo naziv poklicni svetovalec. Oblike tega dela se seveda razlikujejo od države do države. Prelčeva (2007) poudarja, da je v Sloveniji način izobraževanja svetovalnih delavcev drugačen kot $v$ večini drugih evropskih držav. Pri nas ni programov za pridobitev kvalifikacije za poklicno orientacijo. Kar zadeva izobrazbeno ozadje, lahko svetovalne storitve ponujajo pedagogi, psihologi, socialni delavci, socialni pedagogi ter specialni in rehabilitacijski pedagogi. Vsi imajo profesionalno izobrazbo za izvajanje svetovalnega dela, vendar le zelo redko tudi posebno izobrazbo iz poklicnega svetovanja in orientacije, ugotavljajo v L\&R Sozialforschung (2010). Menim, da svetovalni delavci pri opravljanju svojih nalog potrebujejo pomoč zavoda za zaposlovanje. Kot je zapisano v programskih smernicah, je celoten program dela usklajen $\mathrm{z}$ nalogami zavoda na področju poklicnega usmerjanja, informiranja in svetovanja.

\section{LITERATURA IN VIRI}

Brančić, B. (1986). Psihološke teorije izbora zanimanja. Nove tendence u profesionalnoj orijentaciji. Beograd: Naučna knjiga.

Colman, F. (1996). Šolska in poklicna orientacija. Ideje in gradivo za šolsko in poklicno orientacijo. Trst: Avtonomna dežela Furlanija - Julijska krajina. Deželno ravnateljstvo za kulturo in izobraževanje.

Council of the European Union (2008). Council Resolution on better integrating lifelong guidance into lifelong learning strategies. Brussels: $2905^{\text {th }}$ Education, youth and culture Council meeting. Pridobljeno 31. 1. $2011 \mathrm{~s}$ http://www.consilium. europa.eu/uedocs/cms_Data/docs/pressdata/en/ educ/104236.pdf 
Grcić, D., Žerovnik, V. (2005). Poklicna orientacija mladih z manj priložnostmi. V: Klemenčič, M. M. (ur.), Modeli dobre prakse v socialnopedagoškem delu - strokovni izzivi v družbi negotovosti. Zbornik povzetkov 3 . kongresa socialne pedagogike $\mathrm{z}$ mednarodno udeležbo. Pridobljeno 11. 4. 2008. s http://www.zzsp.org/Zbornik_povzetkov_Rogla_2005.doc.

Grcić, D. (2008). Poti mladih v družbi negotovosti. Magistrsko delo. Ljubljana: Univerza v Ljubljani, Pedagoška fakulteta.

Holland, J. L. (1985). The Self-Directed Search. Professional manual - 1985 edition. Odessa: Psychological Assessment resources.

Jakelić, F. (1990). Odgoj u obitelji i izbor zanimanja. Zagreb: Školska knjiga.

Lapajne, Z. (1978). Prispevek k teoriji poklicnega usmerjanja. Ljubljana: Univerza v Ljubljani. Center za razvoj univerze.

Lapajne, Z. (1996). Psihološke teorije izbire poklica. Ljubljana: Republiški zavod za zaposlovanje.

Lapajne, Z. (1997). Psihološke teorije izbire poklica. V: Niklanović (ur.), Kako naj svetujem? Ljubljana.

Lednik, R. (2006). Izboljšanje politik in sistemov vseživljenjske karierne orientacije. Uporaba skupnih evropskih referenčnih orodij. Ljubljana: Zavod Republike Slovenije za zaposlovanje.

LiveCareer. (b. d.). Our free Career Interest Test Can Change your Life! Pridobljeno 20. 6. $2008 \mathrm{~s} \mathrm{http://www.livecareer.com/report/}$ self.asp ?pagecd $=$ SELF $\&$ guid $=\{$ DEC7B $3 A D$ -D90C-41CB-B36A-D9A2FE9D5F3F $\}$ \& $\mathrm{nc}=7557545.805192089$.

L\&R Sozialforschung (2010). Zbirka primerov boljše integracije poklicne orientacije in informiranja $v$ šolski pouk na obmejnem območju med Slovenijo in Avstrijo. Dunaj: L\&R Sozialforschung/ EXPAK AT.SI.

Marjanovič Umek, L., Zupančič, M. (2004). Razvojna psihologija. Ljubljana: Znanstvenoraziskovalni inštitut Filozofske fakultete.

Niklanović, S. (1997). Kako naj svetujem. Prispevki o poklicnem svetovanju. Ljubljana: Izida.

Niklanović, S. (1998). Kako naj svetujem. Prispevki o poklicnem svetovanju. Ljubljana: Izida.

Niklanović, S. (2005). Iskanje poklicne poti. Ljubljana: Center za psihodiagnostična sredstva.

Niklanović, S. (2007). Pregled politike karierne orientacije v EU. Resolucija o karierni orientaciji. Ljubljana: Zavod Republike Slovenije za zaposlovanje.

Niklanović, S. in dr. (2009). Strokovne podlage za izgradnjo sistemskega pristopa $k$ vseživljenjski karierni orientaciji v okviru operativnega programa razvoja človeških virov (Vseživljenjska karierna orientacija 2009). Ljubljana: Kadis d.o.o.

Pelc, J. (2007). Odziv svetovalnih delavcev na teze za javno razpravo ob spremembah in dopolnitvah zakona o organizaciji in financiranju vzgoje in izobraževanja. Pridobljeno 10. 2. 2008 s http://www2. arne:si/ dpsih/priloge/JulijaPelc\%20SolskeSvetSluzbe\%20na\%20 prepihu\%2020-4-2007.doc.

Podlogar, P. (2001). Poklicna orientacija v nižjih razredih osnovne šole. Diplomsko delo. Ljubljana: Univerza v Ljubljani, Pedagoška fakulteta.

Poklicno odločanje. Najpogostejše težave uporabnikov. (b. d.). Pridobljeno 6. 6. $2006 \mathrm{~s} \mathrm{http://www.izida.si/}$ poklicno_odlocanje-najpogostejse_tezave.htm.

Rupar, B. (1999). »Poklicna orientacija v programskih smernicah šolske svetovalne službe«. Šolsko svetovalno delo, 4: 13-17.

Špende, B. (2002). »Kako predstaviti različne poklice«. Šolsko svetovalno delo, 2: 23-25.

Zakon o urejanju trga dela (ZUTD). V: Uradni list RS, št. 80 (z dne 12. 10. 2010).

Žerovnik, V. (1997). Iskanje pravega poklica. Priročnik za delo svetovalcev, učiteljev in staršev. Ljubljana: Izida. 